\author{
MACIEJ PTASZYŃSKI \\ Instytut Historyczny \\ Uniwersytetu Warszawskiego
}

\title{
CHRZEŚCIJAŃSTWO WOBEC ZMIANY: PRZYPADEK REFORMACJI
}

Na wieść o śmierci siostry dominikanin Martin Gruneweg (1562-1618) rozpoczął spisywać wspomnienia, wspomagając osłabiony już wiekiem wzrok okularami. Jego zapiski były jednak nie tylko osobistą historią nawrócenia, lecz także dziejami rodziny i rodzinnego miasta, Gdańska ${ }^{1}$. W ten sposób we wspomnieniach dominikanina znalazła się średniowieczna kronika rozszerzona o historię gdańskiej reformacji. Pod wpływem matki konwertyta wplótł do swojej opowieści dzieje reformacji, choć pominął wiele aspektów własnego wychowania w luterańskim mieście. Podczas jego wizyty w Gdańsku w 1587 r. matka poprosiła go o przepisanie starej księgi domowej, prowadzonej przez nią i jej przodków. Kobieta potrafiła wprawdzie dobrze czytać i pisać, ale rękopiśmienne zapiski sprawiały jej kłopot. Martinowi również pismo wydawało się w wielu miejscach nieczytelne, a przecież za niewielkie pieniądze mógł kupić piękniejsze książki. Cóż można znaleźć w tej księdze, czego nie byłoby w innych? Gdy matka nie ustępowała, Martin dodał, że zapomniał już niemieckiego, wiele lat przebywając wśród narodów posługujących się innymi językami. „Byłem i jestem nie-niemiecki” („ich joe so undeutz war (oder noch bin)"). Mimo to wziął ze sobą księgę i gdy w końcu matka zażądała jej zwrotu, zasiadł do lektury i wywiązał się z zobowiązania ${ }^{2}$.

Historia opowiedziana przez Grunewega odsłania złożony splot okoliczności, w których nieraz powstawała historia reformacji. W tym wypad-

${ }^{1}$ Die Aufzeichnungen des Dominikaners Martin Gruneweg (1562 - ca. 1618) über seine Familie in Danzig, seine Handelsreisen in Osteuropa und sein Klosterleben in Polen, wyd. A. Bues, Wiesbaden 2008, t. 1, s. 4-5.

${ }^{2}$ Ibidem, s. 44-45. 
ku spisywana na kartach dzieła będącego historią nawrócenia gdańskiego luteranina, który po niemiecku napisał o sobie, że nie jest Niemcem. Spór między matką a Martinem unaocznia także ogromną przepaść cywilizacyjną powstałą w XVI w. i oddzielającą pokolenia wychowane w kulturze rękopisu, będącego zawsze bezcennym unikatem, od generacji korzystających z druku, który powielał treści, czyniąc je łatwo dostępnymi. Prowokuje także do pytania o zmianę, jaką przyniosła ze sobą reformacja, a także o stosunek do tradycji i centralnych idei chrześcijaństwa, o które zapytała Redakcja „Kwartalnika Historycznego”.

Ów zwrot reformacyjny był definiowany na początku XVI w. dość swoiście. Podstawę działań reformatorów stanowiła potrzeba powrotu do początków, rozumianych jako czyste i niezmącone źródło zasad rządzących chrześcijaństwem. Zapoczątkowany wówczas ruch nie miał być radykalnym zerwaniem z przeszłością, lecz jedynie odnową i powrotem do ewangelicznego chrześcijaństwa, od którego miał się oddalić Kościół późnego średniowiecza. W ocenie naukowców ów zwrot przyniósł jednak drastyczne zmiany w obrębie teologii i religijności, stosunków społecznych oraz układu sił politycznych. W tym miejscu zmiany reformacyjne dotykają pytania postawionego przez Redakcję na temat wpływu chrystianizacji na struktury polityczne.

Trzecim zagadnieniem poruszonym przez Redakcję jest kwestia laicyzacji Europy. Reformacja miała zapoczątkować szereg przemian prowadzących do sekularyzacji społeczeństwa i odsunięcia religii w zaścianek prywatności. W dalszych rozważaniach podjęto próbę syntetycznego opisu natury reformacyjnego zwrotu oraz jego reinterpretacji w historiografii.

Początek zmianom dał spór o odpusty. 31 października 1517 r. Marcin Luter ogłosił tezy, w których poddał krytyce praktykę sprzedaży odpustów, uderzając także w papieża i niektóre fundamenty średniowiecznego Kościoła. Równolegle z Lutrem w Szwajcarii przeciw odpustom i nadużyciom kościelnym wystąpił Ulrich Zwingli. W tę teologiczną debatę włączali się kolejni duchowni, a Rzym wytoczył w 1518 r. proces Lutrowi, zakończony w latach 1520-1521 bullami potępiającymi jego naukę i wykluczającymi go z Kościoła.

W ciągu trzech lat, dzielących wystąpienie przeciw odpustom i potępienie, Luter sformułował podstawy nowej teologii. Wysiłkiem wielu współpracowników nowa teologia została usystematyzowana w wyznaniach wiary, była propagowana w katechizmach i legła $u$ podstaw organizacji struktur eklezjalnych. Propagowanie tych treści w katechizmach, literaturze religijnej czy drukach polemicznych, a także za pośrednictwem szkoły, wizytacji kościelnych i regularnie odprawianej spowiedzi, 
z pewnością służyło poprawie znajomości prawd wiary i pogłębieniu religijności. Ponieważ ludność poddana tym zabiegom należała już do kultury chrześcijańskiej, zjawisko to bywa określane mianem ewangelizacji. Niewiedza wiernych i duchownych obnażona przez wizytacje w parafiach była jednak tak głęboka, że ewangelizacja musiała czasem oznaczać przekazanie bardzo rudymentarnych zasad. Bliski współpracownik Lutra, Filip Melanchton, relacjonował po wizytacji, że pastor zapytany, czy pilnie przedstawia swym słuchaczom dekalog, odpowiedział, że jeszcze nie ma książki owego „Dekaloga”. Natomiast skargi wizytatorów na pogaństwo wiernych żyjących na granicach ówczesnej Europy - na przykład w Prusach - były zapewne w dużym stopniu humanistyczną kalką i uczonym konstruktem.

Ewangelizacja oznaczała przekaz prostych zasad, sprawdzenie stanu parafii i poziomu życia kleru oraz wiernych. $Z$ jednej strony sprowadzano więc kwestie wiary do wiedzy, recytowania formuł oraz instytucjonalnych ram. $Z$ drugiej strony, pojęcie wiary było przez reformatorów silnie zinterioryzowane, a być może nawet zindywidualizowane ${ }^{3}$. Punktem wyjścia ich refleksji była przecież krytyka skostniałej i sformalizowanej średniowiecznej pobożności. Przekładając Biblię, liturgię oraz teksty modlitwy i pieśni na języki narodowe, oczekiwano, że wierni nie tylko będę je powtarzać, lecz także rozumieć. Wraz ze zmianą języka tekstów modlitewnych zmieniały się także oczekiwana w stosunku do zachowań wiernych: coraz mniej ważna stawała się liczba powtórzeń tradycyjnych formuł, a coraz bardziej ich rozumienie i przeżycie. Luter pragnął, aby podczas modlitwy serce wiernego zapłonęło niezależnie od wypowiadanych słów. Sam przyznawał, że nie przywiązuje wagi do konkretnych sformułowań, lecz układa modlitwy spontanicznie, wedle nastroju i potrzeby. Nie miało dla niego także znaczenia, czy wierny podczas modlitwy stoi, klęczy czy leży.

Spór o reformację szybko przestał być wyłącznie starciem w łonie Kościoła, lecz zyskał zainteresowanie społeczeństwa, do którego walczące strony docierały zarówno za pośrednictwem żywego słowa, jak i druku. Polemiki oraz pisma ulotne komentujące aktualne wydarzenia cieszyły się ogromną popularnością i rozchodziły w dużych nakładach, nadając całej debacie bardzo medialny charakter. Reformacja nie była jednak po prostu kontynuacją rewolucji Gutenberga, a związek kultury druku z kształtowaniem się kultur konfesyjnych był bardziej złożony.

${ }^{3}$ Por. W. Kriegseisen, Autonomia jednostki a wolność sumienia. Problem konwersji w nowożytnej Rzeczypospolitej, w: Autonomia jednostki w Europie i w Polsce od XVII do XX wieku, red. W. Mędrzecki, Warszawa 2011, s. 25-44. 
Być może to nie tylko druk pomógł reformacji, lecz także reformacja uratowała wynalazek druku, dostarczając drukarzom i księgarzom ciekawych treści ${ }^{4}$. Można tu przypomnieć rodzinę Grunewega, gdzie to matka luteranka reprezentowała w latach osiemdziesiątych XVI w. przywiązanie do kultury rękopisu, a Gruneweg - katolik - wypowiadał się jako człowiek druku. Być może odzwierciedlało to do pewnego stopnia specyfikę Rzeczypospolitej, gdzie słabość drukarstwa protestanckiego stała w jaskrawym kontraście do żywej wymiany korespondencji z ośrodkami reformacji w Rzeszy i Szwajcarii. Słabość tę, objawiającą się niewielką liczbą edycji dzieł zachodnich teologów oraz jeszcze skromniejszą liczbą przekładów, można wyjaśnić łatwością importu książek. Być może jednak była to cecha charakterystyczna reformacji, która zaczęła żywiej rozwijać się w Rzeczypospolitej dopiero w latach czterdziestych. Reformatorom zależało wówczas na nawiązaniu osobistego i bliższego kontaktu z kluczowymi postaciami sfery politycznej. Wraz z zyskaniem przez reformatorów poparcia władz miejskich i książąt debata przerodziła się w starcie polityczne, toczone najpierw na forum lokalnym, następnie na arenie zgromadzeń stanowych i w końcu - europejskich polach bitew. Konsekwencją oficjalnego oderwania Kościoła lokalnego od Rzymu było podporządkowanie władzy świeckiej (w ustrojach episkopalnych) lub silniejsze wprowadzenie świeckich do struktur kościelnych (w ustrojach prezbiterialnych).

Rozwojowi reformacji od początku towarzyszyły dyskusje nad jej źródłami, znaczeniem oraz dziejami. Konstruowanie własnej tożsamości przez protestantów dokonywało się bowiem już w XVI w. także poprzez wpisanie historii reformacji na karty dziejów chrześcijaństwa zarówno na płaszczyźnie biograficznej, lokalnej, jak i uniwersalnej. Luter czy Jan Kalwin chętnie stylizowali długą drogę rozwoju duchowego i intelektualnego na nagłe nawrócenie (subita conversio), przypominające historię św. Pawła. Ten pierwszy zmienił pisownię swojego nazwiska z Luder na

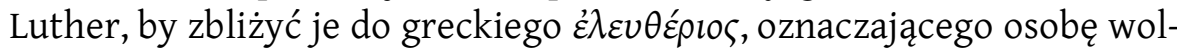
ną oraz przynoszącą wolność . Również Gruneweg nawrócił się momentalnie w wyniku ciężkiej choroby podczas podróży do Porty, a konwersja została poświadczona wizją, podczas której ukazali mu się nieznany święty i anioł, który zabrał go do Jerozolimy, gdzie przemówił do niego w języku polskim 6 .W dziejach miast i prowincji pojawiały się sformułowania o jaśniejącym świetle ewangelii (lux evangeliae), wydobywającym

${ }^{4}$ J. Burkhardt, Stulecie reformacji w Niemczech (1517-1617). Między rewolucja medialna a przełomem instytucjonalnym, Warszawa 2009 (oryg. niem. 2002), s. 14, 40.

${ }^{5}$ H. Schilling, Martin Luther. Rebell in einer Zeit des Umbruchs, München 2012, s. $170-172$.

${ }^{6}$ Die Aufzeichnungen, t. 2, s. 986-998, 1002. 
chrześcijan z mroku. Zwolennicy nowej nauki zostali ipso facto włączeni do katalogu „świadków prawdy”, wraz z Apostołami, Ewangelistami, starożytnymi Ojcami Kościoła oraz wybranymi przedstawicielami Kościoła średniowiecznego, wśród których ważne miejsce zajął Jan Hus.

Z punktu widzenia dzisiejszego stanu wiedzy wydaje się niewątpliwe, iż celem takiego konstruowania tożsamości była konfrontacja. Wiele elementów owych „dyskursów tożsamościowych” znalazło odbicie w pisarstwie historycznym wchodzącym w XIX w. w fazę akademizacji ${ }^{7}$. Szczególnie silny wpływ na historiografie narodowe miała wizja ukształtowana przez Leopolda von Rankego, wedle której reformacja była epoką historyczną, rozpoczętą w Rzeszy wystąpieniem Marcina Lutra w 1517 r., a zakończoną przez pokój augsburski w 1555 r. Zwłaszcza po zjednoczeniu Niemiec i odrodzeniu Rzeszy w $1871 \mathrm{r}$. Luter był stylizowany nie tylko na proroka, lecz także na narodowego bohatera i patriotę, którego zestawiano z Goethem i Bismarckiem. Zarówno obchody urodzin Lutra w 1883 r., gdy utworzono Verein für Reformationsgeschichte, jak i jubileuszu reformacji w 1917 r., który zaowocował powołaniem do życia w 1918 r. Luther-Gesellschaft, ukazały szeroką paletę interpretacji postaci reformatora. $\mathrm{W}$ ramach „Luterańskiego renesansu” liberałowie i konserwatyści przedstawiali reformatora jako mieszczanina, zbyt gorliwie podporządkowanego świeckiej zwierzchności i niedojrzałego do demokracji ${ }^{8}$. Na przeciwnym biegunie umieszczano wyznanie reformowane (kalwinizm), które było matecznikiem demokracji, postępu i modernizacji. W tle tych „wielkich narracji” stały oczywiste pytania o stosunek do zmian, które spowodowała nowoczesność: ocenę sekularyzacji społeczeństwa masowego, emancypacji kobiet, demokratyzacji władzy czy urynkowienia gospodarki.

Druga połowa XX w. przyniosła ze sobą relatywizację wszystkich wielkich ocen i konstrukcji, na których oparto owe „wielkie narracje”. Wielokrotnie podważano wizję przyczyn triumfalnego pochodu ruchu reformacyjnego, ukazanego jako iskra trafiająca na beczkę z prochem ${ }^{9}$. U schyłku średniowiecza należy bowiem mówić nie tyle o upadku Kościoła, ile o wzmocnieniu jego pozycji i rozkwicie pobożności. Ożywioną religijność charakteryzował rozkwit kultu świętych, wzrost liczby fundacji oraz organizacji religijnych, a także silnie religijne zabarwienie

${ }^{7}$ Por. szkice historiograficzne np. w: S. Ehrenpreis, U. Lotz-Heumann, Reformation und konfessionelles Zeitalter, Darmstadt 2002, s. 17-62; O. Mörke, Die Reformation. Voraussetzungen und Durchsetzung, München 2005, s. 67-138.

${ }^{8} \mathrm{H}$. Assel, Der andere Aufbruch. Die Lutherrenaissance - Ursprünge, Aporien und Wege: Karl Holl, Emanuel Hirsch, Rudolf Hermann (1910-1935), Göttingen 1994.

${ }^{9}$ O. Mörke, op. cit., s. 70-72; B. Moeller, Deutschland im Zeitalter der Reformation, Göttingen 1999 (wyd. 4), s. 36-40. 
organizacji zawodowych i stanowych. Rewersem tego samego medalu były procesy o czary, liczne zjawiska cudowne, fascynacja astrologią i chiliazmem. Być może Kościół i księża nie potrafili zaspokoić potrzeb wiernych i sprostać wyzwaniom owej „afektowanej pobożności”, lecz zarazem już przed 1517 r. głosy krytyki i wezwania do reformy bardzo donośnie brzmiały w łonie samego Kościoła.

Sam Luter, którego mentorem był Johann von Staupitz, teolog głoszący potrzebę odnowy religijności, również wyrósł w duchu ,afektowanej pobożności”. Należy pamiętać, że przed dokonanym przez niego przekładem Biblia była wielokrotnie tłumaczona na języki narodowe - zarówno w całości,jak i we fragmentach. Także proces interioryzacji pojęcia wiary i zmiany stosunku do gestów modlitewnych miał dłuższą metrykę. Na pytanie, czy modlitwa Ojcze nasz zachowuje ważność, gdy modlący nie rozumie wypowiadanych słów, jeszcze Jordan z Saksonii (†1237) mógł odpowiedzieć, że „perła zachowuje wartość, niezależnie od tego, czy jej właściciel wie, ile jest warta”. Jednak już na przełomie XIV i XV w. odpowiedź bywała formułowana w sposób bardziej zawiły: „dobry miecz jest tak samo dobry w rękach wojownika, jak i w rękach łamagi, [- - ] ale dobry wojownik potrafi się z nim lepiej obchodzić niż łamaga. Podobnie jak książka jest tak samo dobra w rękach dziecka,jak i nauczyciela.Jednakże nauczyciel może ją pożyteczniej wykorzystać”. Słowa „nie rozumiem Paternoster” zaczęły wówczas służyć za przykład poważnego grzechu w podręcznikach spowiedzi ${ }^{10}$.

Owa refleksja, ukazująca reformację jako fragment, zwieńczenie lub przerwanie długiego procesu reformy Kościoła, podważyła jej epokowy charakter. Reformacja w drugiej połowie XX w. często bywała rozumiana jako część „,czasu reform”, trwającego od XIII do XVII w. ${ }^{11}$ Relatywizacja znaczenia reformacji jako epoki oraz zakwestionowanie przełomowej roli wydarzeń 1517 r. w szerszej perspektywie historiograficznej wpisywały się w powracające w XX w. próby ukazania ciągłości średniowiecza i nowożytności, zmierzające do zakwestionowania periodyzacji wypracowanej w poprzednim stuleciu. W historiografii anglosaskiej tę tendencję określono nawet jako „bunt mediewistów”"12.

Również badacze epoki nowożytnej przyczynili się do podważenia epokowego znaczenie reformacji. Na opisanie procesów, które wywołała przemiana reformacyjna, niemieccy uczeni ukuli w latach siedemdziesią-

10 Przykłady zaczerpnięte z: T. Lentes, „Andacht” und „Gebärde”. Das religiöse Ausdrucksverhalten, w: Kulturelle Reformation. Sinnformationen im Umbruch 1400-1600, red. B. Jussen, C. Koslofsky, Göttingen 1999, s. 29-67, tu s. 36.

${ }_{11}$ P. Chaunu, Czas reform. Historia religii i cywilizacji (1250-1550), Warszawa 1989 (oryg. franc. 1975).

${ }^{12}$ Zob. W. Caferro, Contesting the Renaissance, Oxford 2011, s. 8-12. 
tych XX w. termin „konfesjonalizacja”, oznaczający zarówno „epokę po reformacji", jak i szereg zmian zachodzących na styku struktur społecznych, kościelnych i politycznych. Konfesjonalizacja miałaby polegać na utworzeniu spójnych wewnętrznie grup wyznaniowych, zorganizowanych w Kościoły, których funkcjonowanie uregulowano prawnie, dogmatykę - ujednolicono, a formy religijności - uporządkowano. Oznaczałaby także powstanie jednolitego konfesyjnie i terytorialnego państwa. Państwo i Kościół za pośrednictwem instytucji szkoły oraz poprzez stawianie wymagań wyznawcom zmieniały kształt relacji społecznych, formując zdyscyplinowane społeczeństwo poddanych. Osobno każdy z tych procesów został już dawno opisany, jednak w ujęciu zaproponowanym przez twórców koncepcji kluczowe było nie tyle wystąpienie tych zjawisk, ile ich wzajemne zazębianie się.

Na zakończenie wypada wrócić do autobiografii Grunewega, spisanej ponad pół wieku po wystąpieniu Lutra. Jej lektura nie zawsze pozwala odpowiedzieć na pytanie, w co przed konwersją wierzył przyszły dominikanin. Wychowany w protestanckim mieście, będąc osobą niezwykle pobożną, z chęcią zwiedzał katolickie kościoły, z wiarą relacjonował doniesienia o cudach podczas procesji, na szyi nosił relikwie świętego krzyża, a czasami miewał we śnie religijne wizje ${ }^{13}$. Ten opis luterańskiej pobożności widzianej przez okulary katolickiego duchownego uświadamia, jak wolno ewoluowały społeczne praktyki, mimo zmiany przepisów, norm i instytucji.

Przykład ten unaocznia także tezę, że często łatwiej powiedzieć, czym reformacja nie jest i w jaki sposób z pewnością nie wpłynęła na rozwój chrześcijaństwa. Szereg procesów, które uruchomiła - jak konstruowanie nowych struktur eklezjalnych, opanowanie szkolnictwa, dyscyplinowanie wiernych czy związek z aparatem państwowym - należy przyporządkować do następującej po reformacji epoki konfesjonalizacji. „Rewolta mediewistów" oraz popularność teorii konfesjonalizacji doprowadziły początkowo do utraty przez reformację statusu epoki historycznej, a nawet do „zagubienia reformacji” ${ }^{14}$.Zarazem jednak wyodrębnienie procesu konfesjonalizacji umożliwia oddzielenie rewolty teologicznej skierowanej przeciw staremu porządkowi od procesów budowania nowych wyznań i Kościołów.

Wbrew sceptycyzmowi, do którego może skłaniać zestawienie tak rozbieżnych ocen historiografii, z gąszczu interpretacji można wydobyć ustalenia istotne dla opisu dziejów reformacji, oceny jej sukcesów

${ }^{13}$ Die Aufzeichnungen, t. 2, s. 588-589, 597, 617.

${ }^{14} \mathrm{H}$. Schilling, Reformacja - przełom czy szczyt swoistego Temps des Réformes, w: idem, Konfesjonalizacja. Kościót i państwo w Europie doby przednowoczesnej, Poznań 2012, s. 104-124. 
i porażek oraz wpływu na stan religijności społeczeństwa. Dynamiczne przemiany w obrębie zachodniego chrześcijaństwa, których świadkiem była epoka nowożytna, ukazują, jak podatna na zmiany i elastyczna była idea chrześcijaństwa. Wielkim znaczeniem reformacji z punktu widzenia dziejów chrześcijaństwa było pogłębienie refleksji na temat przekazu biblijnego oraz intensyfikacja religijności. Zainicjowane przez nią zmiany oddziaływały również na Kościół katolicki, stąd uprawnione jest mówienie o reformie katolickiej jako procesie równoległym do reformacji protestanckiej. Owa przemiana zachodniego chrześcijaństwa w oczywisty sposób wywołała lub wpisywała się w szereg przeobrażeń modernizujących Kościół, społeczeństwo i państwa u progu epoki nowożytnej. Obserwacja ta zachowuje ważność niezależnie od intencji reformatorów, chcących jedynie wrócić do czasów ewangelii, oraz interpretacji historyków, szukających w historii odpowiedzi na wyzwania nowoczesności, do których należy również postępująca laicyzacja. Opis i ocena przemiany okresu reformacji były od XVI w. przedmiotem sporów, co także unaocznia, do jakiego stopnia idea chrześcijaństwa jest również społeczną konstrukcją, redefiniowaną w kolejnych epokach, zależnie od aktualnych wyzwań i potrzeb. 